\title{
A preliminary phyto-pharmacognostical evaluation of Opuntia elatior Mill. (Nagaphani or Hathalo-thore) fruit
}

\author{
Research article
}

\author{
Hemil Patel $^{*}$, Shashikant Prajapati ${ }^{2}$, Rabinarayan Acharya ${ }^{3}$, Harisha CR $^{4}$, Vinay Shukla \\ 1. M.D Scholar, 2. Ph.D Scholar, 3. Professor, Dravyaguna Department, \\ 4. Head, Pharmacognosy laboratory, 5. Head, \\ IPGT \& RA, Gujarat Ayurved University, Jamnagar
}

\begin{abstract}
In Gujarat, Opuntia elatior Mill., a member of Cactaceae family known as Nagaphani or Hathlo-thore has been reported for its traditional uses as a medicinal plant. It is used as remedy in different disease conditions like anaemia, asthma etc. by tribal of Gujarat state. A detailed pharmacognostical character and pharmaceutical analysis of its fruit is not reported still yet. An attempt has been made to study the macroscopic, microscopic, physicochemical parameters and HPTLC profile of its fruit following standard procedures. Results show in Transverse section of unripe fruit, presence of outer exocarp layer with rosette crystals, followed by mesocarp and inner endocarp. Transverse section of ripen fruits, shows presence of same characters as fresh unripe fruit except the presence of betacyanins in its mesocarp layer. Powder microscopy of mature fruit shows diagnostic characters like multicellular tri chomes, rosette crystals of calcium oxalate, coloring matter and starch grains. The ash value of $O$. elatior fruit is $3.59 \% \mathrm{w} / \mathrm{w}, \mathrm{pH}-5.27$, total solid content $-10.83 \%$, viscosity -5.11 and Specific gravity is 1.042 . HPTLC study showed the presence of four and two spots in short and long UV respectively, among them, 0.04 and 0.97 are the common $\mathrm{R}_{\mathrm{f}}$ value. These observed pharmacognostical, physicochemical parameters and HPTLC profile may be useful to establish the botanical standards for identification and standardization of $O$. elatior fruit.
\end{abstract}

Key words: Hathalo-thore, Nagapheni, Opuntia elatior Mill, Pharmacognosy, Physicochemical

\section{Introduction}

A folklore medicinal plant, widely prevalent in the state of Gujarat, known as "Hathlo thore", botanically identified as Opuntia elatior Mill. of family Cactaceae.(1) This family is containing about 130 genera including the genus Opuntia and nearly 1500 species.(2) Cactaceae family is well adapted to arid and semiarid climates, where water shall be a limiting factor for cultivation. $(3,4)$ It is found that all cacti in India did not belong to one species, but to three or four species distributed over different regions in India. Opuntia dillenii Haw. is found mainly in the southern parts of the India while $O$. vulgaris Mill (Syn Opuntia monocantha Haw.) is distributed mainly in the northern parts; $O$. elatior Mill. is being reported in western India. (5) Among them, O. elatior is available in Saurashtra region of Gujarat with a vernacular name 'hathlo thore' $O$. elatior (6) can be differentiated from other by presence of 2-5 spines in each areole and the characteristic colour changes in flower at various stages (i.e from yellow at first to pink and finally bright red). Opuntia elatior is fleshy, succulent, perennial herbs, shrub with spines or bristles or both available in Gujarat, Rajasthan, Orissa and central India, and

\footnotetext{
*Corresponding Author:

Dr. Hemil Patel

MD Scholar,

Dravyaguna Department,

IPGT\&RA, Gujarat Ayurved University, Jamnagar

Phone number: 09909355336

E-mail: hemil.pate1211@gmail.com
}

distributed chiefly in semi-desert or drier regions of tropical and subtropical America and also in Africa, Mauritius, Seychelles, Sri Lanka, and Australia.(7)

Opuntia elatior Mill. possesses varied ethnobotanical claims in different diseases. In asthma baked fruits is administered internally once in a day for a week(8), pulp of one ripe fruit is used for burning sensation in the stomach(9), fruits first heated and then powdered, about $5 \mathrm{~g}$ powder consumed at morning for 10-15 days in rheumatism(10), juice of 7-8 fruits is mixed with $50 \mathrm{gm}$ jaggery and taken orally by the tribal ladies for 2-3 days to develop complete sterility(11) and in whooping cough baked fruit and fruit syrup is increases the flow of bile and control spasmodic cough and expectoration.(12) This plant is used internally to relieve muscle spasms, whooping cough, cough, stomach ache \& inflammation in diphtheria. Its external application is well appreciated in abscesses, boils, measles, etc. $(13,14)$

Recent literature review reveals that the various parts used of the plant Opuntia elatior Mill. has not been studied for its pharmacognostical characters till date. Hence, the present study was undertaken to establish certain botanical standards for identification and standardization of fruits of Opuntia elatior Mill.

\section{Materials and Methods}

Fresh fruits of Opuntia elatior Mill. were used as material for this study. The study was conducted as per the guidelines of Ayurvedic Pharmacopoeia of India. (15) 


\section{Collection and authentification of sample}

The plant Hathlo thore (Opuntia elatior Mill.)

fruit was collected from its natural habitat, suburbs of Jamnagar, Gujarat, during November 2013 and authenticated by local taxonomist. Fruits were separated from the plant and preserved (SPECIMEN NO- PHM-6138/1/1/2014). The collected plant samples were washed under running fresh tap water to remove adherent soil and dirt.

\section{Pharmacognostical Analysis \\ Organoleptic study:}

Fresh and ripen samples of fruit of Opuntia elatior Mill. was evaluated for their organoleptic characters including taste, odour, colour, and touch. (16)

\section{Macroscopic study:}

Macroscopic characters of fruit Opuntia elatior Mill. was studied systematically as per the standard text book of Botany(17) as well as with the help of floras. $(18,19,20)$

\section{a. Morphology}

Collected fruits were observed carefully for its identical morphological characters. Morphological characters like colour, shape, size were noted down. Characters of fruit were studied as per taxonomy(21) and measurement was taken by scale through naked eyes.

\section{b. Microscopic study}

Fresh fruits were taken for detailed microscopic study. Free hand sections of fruit were taken. Microphotographs were taken by using Carl Zeiss Trinocular microscope attached with camera. Same procedure was followed for detailed powder microscopy.(22)

\section{Pharmaceutical Analysis \\ Physicochemical analysis:}

Fruit Swarasa of Opuntia elatior Mill. was used to carry out different parameters as mentioned in Ayurvedic Pharmacopoeia of India. $\mathrm{pH}$ value, Specific gravity, Total solid content, Moisture content, Ash value and Viscosity were determined following standard procedure in API.(23)

\section{Determination of $\mathrm{pH}$ Value}

$20 \mathrm{ml}$ of sample (fruit swarasa) was taken. $\mathrm{pH}$ of the sample were noted with the help of the $\mathrm{pH}$ paper. $\mathrm{pH}-5.22$. Volume taken $=20 \mathrm{ml}$

$$
\begin{aligned}
& \text { Weight of empty bottle (a) } \quad 17.074 \mathrm{~g} \\
& \text { Weight of Sample + bottle (b) } 43.500 \mathrm{~g} \\
& \text { Weight of Sample (b-a) } \\
& 43.500-17.074=26.43 \mathrm{~g} \\
& \text { Weight of bottle + Distilled } 42.428 \mathrm{~g} \\
& \text { water } \\
& \text { Weight of Distilled water } \\
& \text { (d-a) } \\
& \text { (42.428-17.074) g } \\
& =25.354 \mathrm{~g}
\end{aligned}
$$

Specific gravity

Weight of sample

Weight of Distilled water

$=26.426 / 25.354=1.0423$

$\begin{array}{ll}\text { Total solid content } & \\ \text { Weigth of dish + sample } & 56.700 \mathrm{~g} \\ \text { Weight of dish } & 54.535 \mathrm{~g} \\ \text { Weight of solid content } & 2.165 \mathrm{~g} \\ \text { Volume taken of sample } & 20 \mathrm{ml} \\ \text { Total solid content } & \frac{\text { Wt. of solid content X 100 }}{\text { Volume taken }} \\ & =2.165 \times 100 / 20 \\ & =10.83 \%\end{array}$

\section{Specific Gravity}

\section{Moisture content}

Estimation of moisture content O.elatior fruits was carried out five times. Fruit pulp $(10 \mathrm{~g})$ placed in a tarred evaporating dish and dried at $105^{\circ} \mathrm{C}$ in an oven at constant weight. The moisture content and total solids were determined using following equation.(24)

$\%$ Moisture content $=[($ initial weight - dried weight $) /$ initial weight] X $100=74.16 \%$

\section{Determination of Ash value}

$3 g$ of accurately weighed fruit pulp was taken in a tarred silica crucible and incinerated at a temperature not exceeding $450{ }^{\circ} \mathrm{C}$ until free from carbon and constant weight, cooled and weighed.

Total ash $=3.59 \%$

\section{Viscosity}

Determination of Viscosity of OFJ

Viscosity of OFJ was determined five times using spindle S61 of Brookfield viscometer (Model DV-II+ Pro viscometer) at $100 \mathrm{rpm} .(25)$

\section{Chromatographic study:}

HPTLC study was carried out following standard guidelines of API.

Sample for HPTLC:

Alcoholic extracts of fruit Swarasa of Opuntia elatior Mill.

MobilePhase - Toluene: Ethyl acetate: Formic acid $(7.5: 2: 0.5 \mathrm{v} / \mathrm{v})$

\section{Chromatographic conditions}

1. Application mode: Camag Linomat V, 2. Development Chamber: Camag Twin trough Chamber, 3. Plates: Precoated Silica Gel GF254 Plates, 4. Chamber Saturation: $30 \mathrm{~min}, 5$. Development Time: 30 min, 6. Development distance: $8 \mathrm{~cm}, 7$. Scanner: Camag Scanner III, 8. Detection: Deuterium lamp, Tungstan Lamp, 9. Data System: Win cats software. 
Observations and results

Pharmacognostical study

\section{Morphology of fruit}

Fruit berry oval to corn-shape with many clefts of very thin 2-5 spines in each areole all around the fruits and slight brownish in colour. Fruit has multi carpilary syncarpous with many seeds. Average number of seed is 25-30 in a fruit. Measurements of unripe fruit and mature fruit in Table 1 and average weight of fruit in Table 2.

Table 1: Morphology of fruit

\begin{tabular}{|c|l|l|}
\hline Sr. No & Characters & Measurements \\
\hline 1 & Unripe fruit & $4.5 \times 2.8 \mathrm{~cm}$ \\
\hline 2 & Mature fruit & $4.6 \times 2.5 \mathrm{~cm}$ \\
\hline
\end{tabular}

Table 2: Average weight of fruit

\begin{tabular}{|c|l|l|}
\hline Sr. No. & Characters & Weight \\
\hline 1 & Unripe fruit & $9.09 \mathrm{~g}$ \\
\hline 2 & Mature fruit & $12.52 \mathrm{~g}$ \\
\hline 3 & Fruit with flower & $13.19 \mathrm{~g}$ \\
\hline 4 & Flower & $4.10 \mathrm{~g}$ \\
\hline
\end{tabular}

\section{Microscopy of fruit}

\section{T.S. of section of unripe fruit}

Diagrammatic section of the fresh fruit shows outer exocarp, middle mesocarp, inner endocarp and treads into ground tissue.

Exocarp: One to two layers with cortical cells with rosette crystal. Cells square type.

Mesocarp: Comprises large area, made up of parenchyma cells with chlorophyll pigments later on called chlorenchyma. Some of the cells filled with starch grains, rosette crystal of calcium oxalate. Many vascular bundles distributed all over the mesocarp. Some of the specialized cells lead to mucilage cavity.

Endocarp: Endocarp made up of somewhat elongated completely arranged parenchyma cells. Some consist of starch grains and rosette crystal. Endosperm leads into the placenta to the locule. Multi capillary locule consist numerous seeds distributed all over the ground tissues. (Fig. 1a-f)

\section{T.S. of section of matured fruit}

Diagrammatic section of the matured fruit shows outer exocarp, middle mesocarp, inner endocarp and treads into ground tissue.

Exocarp: 1 to 2 layers with critical cells with rosette crystal. Cells square type.

Mesocarp: Comprises large area made up of parenchyma cells with chlorophyll pigments later on largely filled betacyanins (red-violet colour) some of the cells field with starch grains, rosette crystal of calcium oxalate. Many vascular bundles distributed all over the mesocarp. Some of the specialized cells lead to mucilage cavity.

Endocarp: Endocarp made up of somewhat elongated completely arranged parenchyma cells. Consist some of starch grains and rosette crystal. Endosperms leads into the placenta to the lobule multi capillary lobule consists numerous seeds distributed all over the ground tissues. (Fig. 1g-1)

\section{Powder microscopy of fruit}

Powder microscopy showed that presence of multicellular trichomes, rosette crystals of calcium oxalate, coloring matter and starch grains.

\section{Pharmaceutical Analysis}

Physicochemical Analysis

Fruit Swarasa of Opuntia elatior Mill. was tested for various physico-chemical parameters such as ash value, $\mathrm{pH}$, Total solid content (\%), Viscosity, Moisture content. The observed results were depicted in table 3 .

Table 3: Physico-chemical analysis of Oppuntia elatior Mill.

\begin{tabular}{|c|c|c|}
\hline Sr.No & Test & Result \\
\hline 1 & Sp.Gravity & 1.0423 \\
\hline 2 & $\mathrm{pH}$ & 5.27 \\
\hline 3 & $\begin{array}{c}\text { Total solid content } \\
(\%)\end{array}$ & $10.83 \%$ \\
\hline 4 & Viscosity & 5.11 millipoise \\
\hline 5 & Moisture content & $74.16 \%$ \\
\hline 6 & Ash value & $3.59 \%$ \\
\hline
\end{tabular}

Data presented in table 3.4.1 shows the values generated from the physicochemical analysis of fruit Swarasa of Opuntia elatior Mill. Ash value of fruit swarasa is 3.59 $(\% \mathrm{w} / \mathrm{w})$. Total solid content of fruit swarasa is $10.83(\%$ $\mathrm{w} / \mathrm{w})$. Moisture content of fruit swarasa is $74.16(\% \mathrm{w} /$ $\mathrm{w})$. The $\mathrm{pH}$ value of sample is 5.27. Viscosity of fruit Swarasa is 5.11 millipoise. Specific gravity of fruit swarasa is 1.042 .

\section{HPTLC profile:}

Selective alcoholic extract is basically polar and moderately polar component here taken as a fingerprinting proof of Opuntia elatior Mill. After performing the HPTLC chromatogram, it can be suggested that extracts contained different compound. Under UV at $254 \mathrm{~nm}$, most of the bands appeared in fluorescence at different $\mathrm{R}_{\mathrm{f}}$ values. However, under $\mathrm{UV}$ at $366 \mathrm{~nm}$, in fluorescence at different $R_{\mathrm{f}}$. The Pharmacological activities exhibited by of the plant extracts could be attributed to the presence of secondary metabolite (Polyphenol, glycosides, steroids, quaternary ammonium alkaloid) probably in synergism with other compounds. 
Table 4: HPTLC profile of alcoholic extract of Opuntia elatior Mill.

in Toluene: Ethyl acetate: Acetic acid (7:3:1)

\begin{tabular}{|c|c|c|c|c|}
\hline \multicolumn{5}{|c|}{ Data of HPTLC } \\
\hline \multicolumn{5}{|c|}{ Solvent system: Toluene : Ethyl acetate: Acetic } \\
acid (7:3:1 v/v/v) \\
\hline Track & \multicolumn{2}{|c|}{$\begin{array}{c}\text { 254nm } \\
\text { (Short UV) }\end{array}$} & \multicolumn{3}{|c|}{$\begin{array}{c}\text { 366nm } \\
\text { (Long UV) }\end{array}$} \\
& \multicolumn{2}{|c|}{ Nong value } \\
& No of & Rf value & No of & Rf valuts \\
spots & & 2 & 0.04, \\
\hline 1 & 4 & 0.04, & & 0.97 \\
& & 0.16, & & \\
& & 0.92, & & \\
& & 0.97 & & \\
\hline
\end{tabular}

\section{Discussion}

\section{Pharmacognosy}

Opuntia elatior Mill. (cactaceae), is a fleshy, succulent, perennial herbs, shrub with spines or bristles or both. In India, three species of Opuntia are reported. Among them, Opuntia elatior Mill. is available in Saurashtra region of Gujarat with a vernacular name 'hathlo thore' Opuntia elatior Mill.(26) can be differentiated from other by presence of 2-5 spines in each areole and the characteristic colour changes in flower at various stages (i.e from yellow at first to pink and finally bright red). Fruit of $O$. elatior is oval to corn -shaped with many clafts of very thin 2-5 spines and slight brownish in colour. Average number of seeds is 25-30 in a fruit. Unripe fruit is $4.5 \times 2.8 \mathrm{~cm}$ and mature fruit is $4.6 \times 2.5 \mathrm{~cm}$ in size. Average weight of unripe fruit and mature fruit is $9.09 \mathrm{~g}$ and $12.52 \mathrm{~g}$ respectively.

Diagrammatic section of the fresh fruit shows one to two layers of outer exocarp with square shaped cortical cells having rosette crystal. Middle mesocarp comprises large area, made up of parenchyma cells with chlorophyll pigments. Inner endocarp made up of somewhat elongated completely arranged parenchyma cells. Some cells contain starch grains and rosette crystal.

Diagrammatic section of the matured fruit shows outer 1 to 2 layers of outer exocarp with critical cells and rosette crystal. Middle mesocarp comprises large area made up of parenchyma cells with chlorophyll pigments later on largely filled betacyanins. Inner endocarp is made up of parenchyma cells. Consist some of starch grains and rosette crystal. Endosperms leads into the placenta to the lobule multi capillary lobule consists numerous seeds distributed all over the ground tissues.

Powder microscopy of fruit shows diagnostic characters like multicellular trichomes, rosette crystals of calcium oxalate, coloring matter and starch grains.

The observed pharmacognostical characters of Opuntia elatior fruit may be useful to establish the botanical standards for identification and standardization of the plant Opuntia elatior Mill.

\section{Analytical study}

Ash value of fruit Swarasa of Opuntia elatior Mill. fruit was $3.59 \% \mathrm{w} / \mathrm{w}$. The ash value indicates the presence of inorganic and salt materials in the sample. This includes both 'physiological ash' which is derived from the plant tissue itself, and 'non-physiological' ash, which is the residue of the extraneous matter (e.g. sand and soil) adhering to the plant surface.(27) $\mathrm{pH}$ value of the juice is 5.27 which is low. This may be as it is comparatively rich in organic acid. $\mathrm{pH}$ is the main factor affecting the stability of vitamin $\mathrm{C}$, thus high values of $\mathrm{pH}$ favoring the oxidation processes of vitamin $\mathrm{C}(28)$ The overall range of $\mathrm{pH}$ is 2 to 5 for common fruits with the most frequent figures being between 3 and 4.(29)

Total solids contents are related directly to both the sugars and fruit acids as these are the main contributors. Pectins, glycosidic materials and the salts of metals (sodium, potassium, calcium etc.), when present, will also register a small but insignificant influence on the solids figure. In the present study, total solid content of the fruit juice is $10.83 \%$. The total solids content is significantly influenced by the combined effect of stages of maturity and ripening conditions.(30)

Viscosity of the juice is 5.11. Knowledge of the viscosity is of primary importance to the fruit juice industry. The accurate viscosity data over wide temperature and concentration regions are need for a various research and engineering applications in any branch of the food industry, such as developing food processes etc.(31) Specific gravity of the fruit juice is 1.042. Specific gravity is commonly used in industry as a simple means of obtaining information about the concentration of solutions of various materials such as brines, hydrocarbons, sugar solutions (syrups, juices, honeys, brewers wort, must etc.) and acids.(32)

The HPTLC is rapid method of drug analysis that can be used to efficiency demonstrate the characteristic constituents of a drug or new plant extract. The technique clearly illustrates differences in chemical composition of plant extracts. In the present study, alcoholic extract of $O$. elatior is studied for high performance thin layer chromatography profile at $254 \mathrm{~nm}$ and $366 \mathrm{~nm}$ frequency. HPTLC study of alcoholic extract of $O$. elatior showed the presence of four(4) and two(2) spots in short and long UV respectively. Among these, 0.04 and 0.97 is the common Rf value found in both the samples.

\section{Conclusion}

The observed parameters of the fruit of Opuntia elatior Mill, like morphology, microscopy, physicochemical parameters and HPTLC profile always constant. It may be useful to establish certain botanical standards for identification and standardization of Opuntia elatior Mill. for the further studies. 


\section{References:-}

1. Shashikant Prajapati, Harisha C R, R N Acharya, Pharmacognostic evaluation of stem of Opuntia elatior Mill. (Nagaphani ). European Journal of Biomedical and Pharmaceutical sciences. 2015; 2 (2); 351-357

2. Manpreet Kaur, Amandeep Kaur, Ramica Sharma, Pharmacological actions of Opuntia ficus indica: A Review. Journal of Applied Pharmaceutical Science. 2012; 2 (7); 15-18

3. Benson L. Cacti of United States and North America Stanford CA. Stanford University Press; 1982.

4. Kuti J.O, Antioxidant compounds from four Opuntia cactus pear fruits varieties. Food chemistry. 2004; $85 ; 527-533$

5. Gamble JS. The Wealth of India, Raw materials, Vol. X. New Delhi; Council of Scientific \& Industrial Research; 2003

6. Patel RI. Forest flora of Gujarat state. 2 ed. Gujarat; Forest Department Gujarat State; 1984. $176 \mathrm{p}$.

7. Chauhan Sanjay P. Phytochemical and pharmacological screening of fruit of Opuntia elatior Mill.; Rajkot; Thesis submitted to Saurashtra University; 2010

8. Patil, G. G., Mali P.Y. and Bhadane V.V, Folk remedies used against respiratory disorders in Jalgoan district, Maharashtra. Natural product radiance. 2008; 7(4); 354-358

9. Kumar S., Parveen F., Goyal S. and Chauhan A, Indigenous herbal coolants for combating heat stress in the hot Indian arid zone. Indian journal of traditional knowledge. 2008; 7(4); 679-682

10. Patil D.A. and Ahir Rao Y.A, Ethno medicinal knowledge of plants used by local people in Buldhana district of Maharashtra India. Journal of Eco biotechnology. 2011; 3(3); 11-17

11. Anita Jain, S. S. Katewa, P. K. Galav, Ambika Nag, Unrecorded Ethno medicinal Uses of Biodiversity from TadgarhRaoli Wildlife Sanctuary, Rajasthan, India. Acta Botanica Yunnanica. 2007; 29(3); 337-344

12. Kaur Ravinder and Vashistha B.D, Ethnobotanical Studies on Karnal District, Haryana. International Research Journal of Biological Sciences. August, 2014; 3(8); 46-55

13. Chauhan Sanjay P. Phytochemical and pharmacological screening of fruit of Opuntia elatior Mill.; Rajkot; Thesis submitted to Saurashtra University; 2010.

14. Prakash R. Itankar, Varsha A. Sontakke, Mohd. Tauqeer, Sonal S. Charde, Antioxidant potential and its relationship with polyphenol content and degree of polymerization in Opuntia elatior Mill. fruits. An international quarterly journal of research in Ayurveda. Oct-Dec, 2014; 35 (4); 423 $-427$

15. Anonymous. The Ayurvedic Pharmacopoeia of India. 1 ed. New Delhi; Government of India Ministry of Health and Family welfare Department of I.S.M. \& H.; 1999. I: Appendix 2.
16. Khandelwal K R. Practical Pharmacognosy. 1 ed. Delhi; Nirali Prakashan; 2001. 149-156p.

17. Datta. AC Botany for degree students. 22 ed. Oxford University Press; 2007. 576p.

18. Anonymous. The Ayurvedic Pharmacopoeia of India. 1 ed. New Delhi; Government of India Ministry of Health and Family welfare Department of I.S.M. \& H.; 1999. I: Appendix 2.

19. Gamble. JS. Flora of the presidency of madras1. Madras; Printed by the Superintendent Government Press; 2011. 548p.

20. Patel RI. Forest flora of Gujarat state. 2 ed. Gujarat; Forest Department Gujarat State; 1984. $176 \mathrm{p}$.

21. Saxena HO. Flora of the Orissa- 2. Bhuvneshwar; Regional research laboratory; April 1995. 761-763p.

22. Trease and Evans. Pharmacognosy. 15 ed. W.B. Sunders Company Ltd; 1996. 569-70p.

23. Anonymous. The Ayurvedic Pharmacopoeia of India, Ed. 1st, Govt. of India, Ministry of Health and Family Welfare, Department of I.S.M. \& H., New Delhi, 1999, Part 1, Vol. 1.p 331

24. Anonymous. The Ayurvedic Pharmacopoeia of India Part I Vol. III New Dehli; published by Govt. of India Ministry of Health \& Family Welfare Dept. of Indian system of Medicine \& Homoeopathy; 1989. 190-191p.

25. Gaud, R.S. and Gupta. G.D. Practical Physical Pharmacy. 1 ed. New Delhi; CBS Publishers \& Distributors; 2006. 29-36p.

26. Patel RI. Forest flora of Gujarat state. 2 ed. Gujarat; Forest Department Gujarat State; 1984. $176 \mathrm{p}$.

27. E book. Quality control methods for medicinal plant materials. World Health Organization Geneva; 31p.

28. Ana Leahu, Cristina Damian, M. Oroian, Sorina Ropciuc, Physico-chemical parameters of fruit juices - evolution during storage. University of Agricultural Sciences and Veterinary Medicine Iasi. June, 2013

29. Tasnim F, Anwar Hossain M, Nusrath S, Kamal Hossain M, Lopa D \& Formuzul Haque KM, Quality Assessment of Industrially Processed Fruit Juices Available in Dhaka City. Bangladesh, Mal J Nutr. 2010; 16(3); 431-438

30. Tasnim F, Anwar Hossain M, Nusrath S, Kamal Hossain M, Lopa D \& Formuzul Haque KM, Quality Assessment of Industrially Processed Fruit Juices Available in Dhaka City. Bangladesh, Mal J Nutr. 2010; 16(3); 431-438

31. Alvarado, J.D. \& Romero, C.H, Physical properties of fruits III Density and viscosity of juices as functions of soluble solids content and temperature. Latin American Applied Research. 1989; 19; 15-21

32. http://en.wikipedia.org/wiki/Specific_gravity 


\section{Photographs}

Figure 1: T.S of Opuntia elatior Mill. fruit

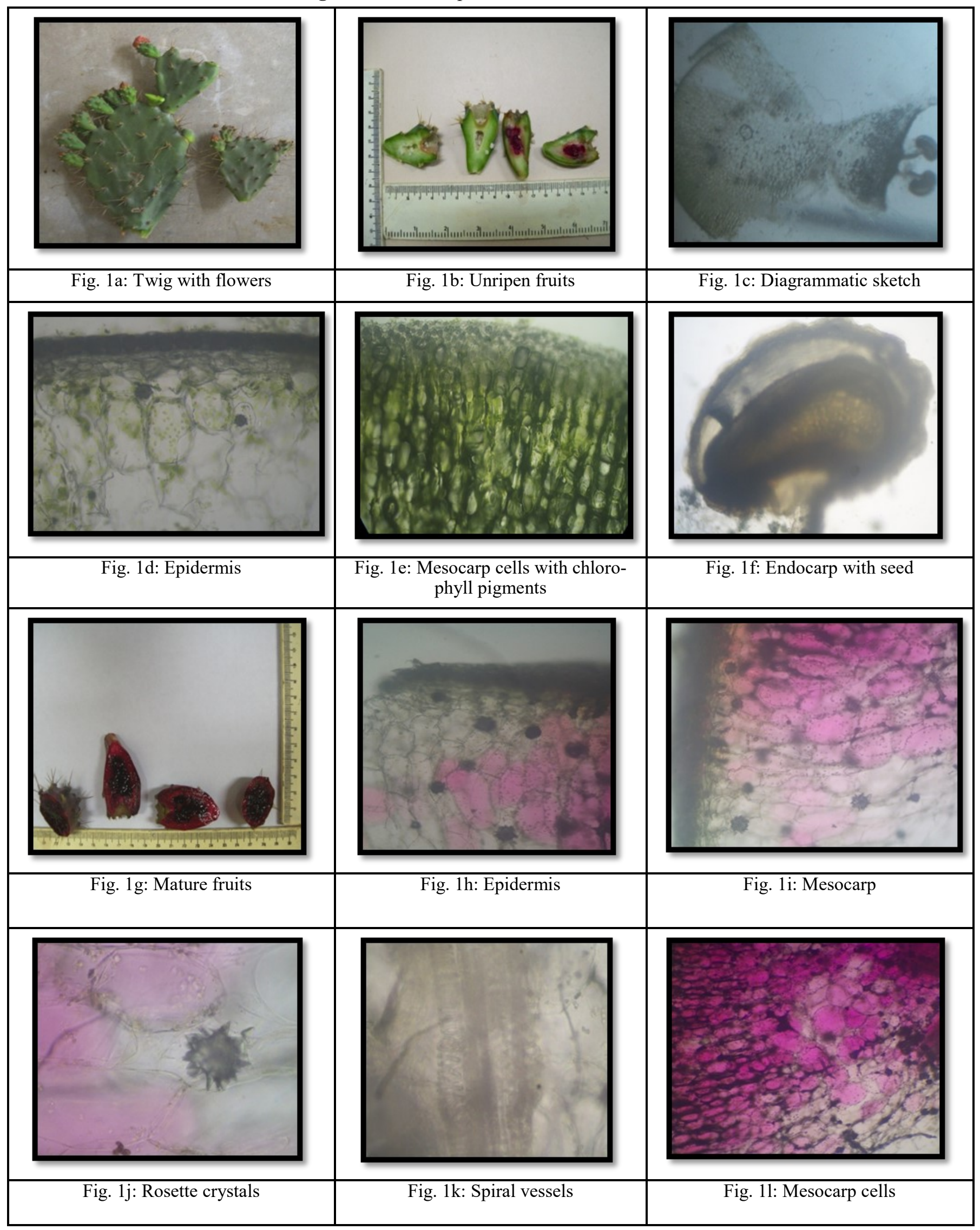




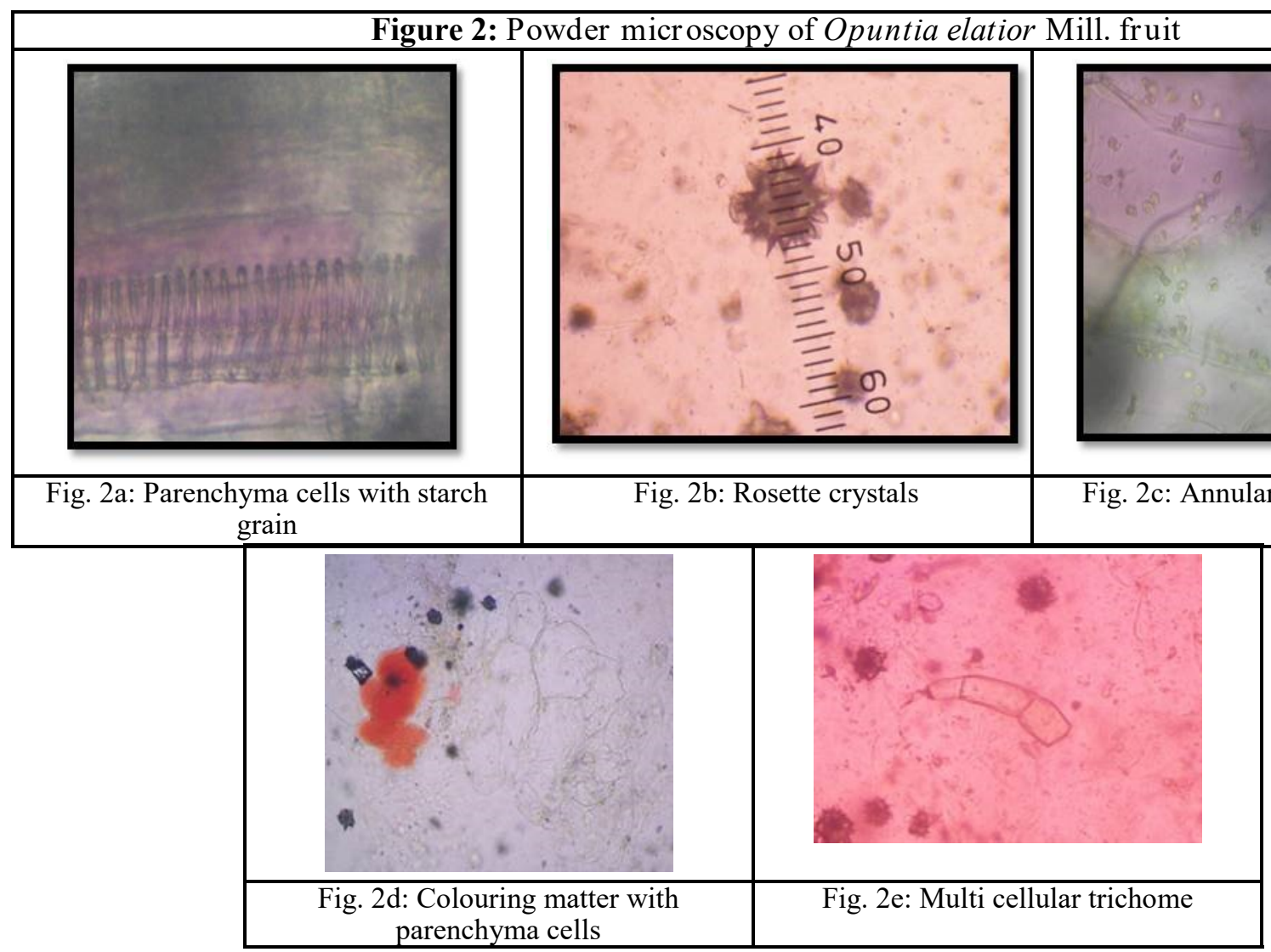

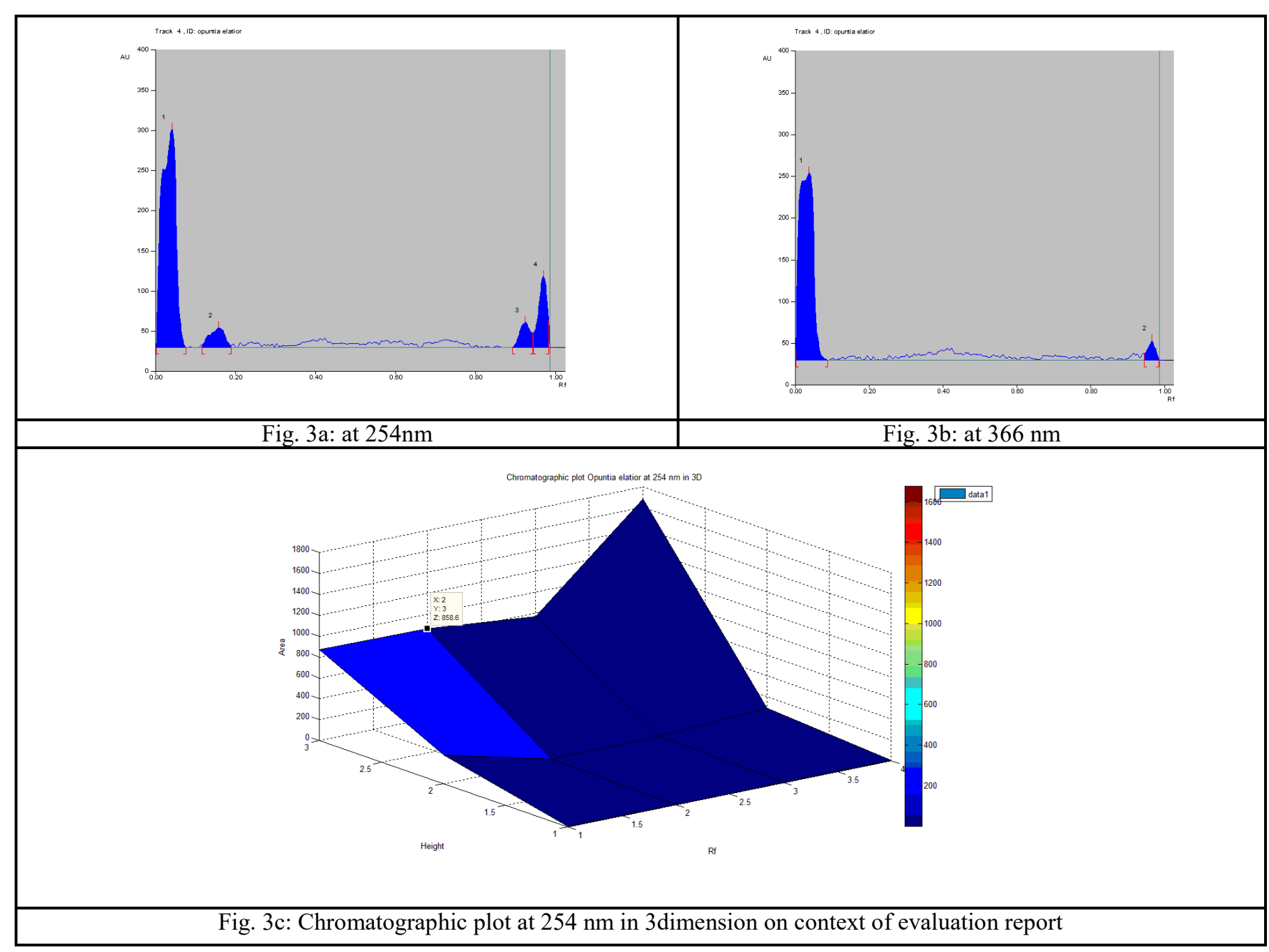

